\title{
Drivers of protistan grazing pressure: seasonal signals of plankton community composition and environmental conditions
}

\author{
Caitlyn Lawrence, Susanne Menden-Deuer* \\ Graduate School of Oceanography, University of Rhode Island, Rhode Island, USA
}

\begin{abstract}
Rates of heterotrophic protist grazing and phytoplankton growth were measured weekly to bi-weekly in Narragansett Bay, Rhode Island, USA, from January 2010 to February 2011. In situ sensor data and species composition were collected concomitantly to link patterns in plankton dynamics with ancillary environmental and biological processes. Annual average phytoplankton growth rates were $0.69 \pm 0.58 \mathrm{~d}^{-1}$, and heterotrophic protist grazing rates were $0.79 \pm$ $0.61 \mathrm{~d}^{-1}$. Phytoplankton growth rates were at times negative in both winter and spring. Nutrient limitation was only detected during summer, and negative growth rates in winter did not result from nutrient limitation. On an annual average, grazing removed 96\% (20 to 200\%) of primary production, with peaks in both phytoplankton growth and heterotrophic protist grazing rates during summer. There was no relationship between protistan herbivory rates and initial chlorophyll $a$ concentration. Dominant grazer taxa changed seasonally. Heterotrophic dinoflagellates dominated in summer and were associated with significantly higher than average grazing rates $\left(>1 \mathrm{~d}^{-1}\right)$. Seasonal changes in grazing rates were most significantly characterized by seasonal changes in both temperature and plankton community composition. The relative effects of temperature and species composition could not be distinguished statistically. The magnitude of protistan grazing and subsequent effects on trophic transfer and primary production rates as well as phytoplankton community composition may be better understood and parameterized when grazing pressure is evaluated in relation to species composition and environmental conditions rather than bulk measures of biomass.
\end{abstract}

KEY WORDS: Heterotrophic protist · Grazing · Seasonal · Dilution · Phytoplankton · Estuary · Food-web dynamics

Resale or republication not permitted without written consent of the publisher

\section{INTRODUCTION}

Primary production in the ocean accounts for approximately $50 \%$ of total global production (Field et al. 1998). Of this, heterotrophic protists, such as ciliates and dinoflagellates, can consume on average $67 \%$ of daily primary production (Calbet \& Landry 2004). It has been suggested that even a quantitatively small disruption of predation pressure relative to phytoplankton growth can lead to large-scale phenomena such as the North Atlantic Spring Bloom (Behrenfeld 2010). Grazing by heterotrophic protists can alter the abundance, community composition, and size structure of phytoplankton, as well as globally important rates of primary and export production. Phytoplankton population dynamics can be analyzed and predicted using models (Franks 2001); however, it has been difficult to parameterize such models and thus establish reliable predictions of the magnitude of grazer-induced mortality rates (Li et al. 2011).

Although the importance of protistan rates of herbivory to phytoplankton production and biomass are now well established from an extensive set of experiments (Calbet \& Landry 2004), it is still unknown what factors drive the magnitude of grazing pressure. Measured grazing rates are frequently not 
related to obvious variables, such as total phytoplankton biomass measured as chlorophyll a ( $\mathrm{chl} a)$ concentration (Strom et al. 2001, Sherr et al. 2009, Menden-Deuer \& Fredrickson 2010). To identify the drivers of protistan herbivory rates, it is important to identify the biotic, environmental, and seasonal factors that govern the magnitude of these grazing rates in order to predict the magnitude of grazing pressure and thus primary production and biomass accumulation rates.

Coastal waters in temperate regions are subject to significant seasonal variation in both environmental conditions and biological processes and thus these ecosystems lend themselves to investigating influences of environmental factors on biological rates. Seasonal grazer-dependent changes in food web structure and plankton assemblage have been identified from detailed studies of both environmental conditions and plankton community composition and production (Tamigneaux et al. 1997). A seasonal study in a coastal Mediterranean lagoon found significant seasonality in picoeukaryote growth rates as well as heterotrophic protist grazing rates, but no seasonal signal for growth of or grazing on phytoplankton $>2 \mu \mathrm{m}$ (Bec et al. 2005). A year-long investigation of nanoplankton population dynamics in Narragansett Bay found that on average, $62 \%$ of daily primary production of the $<5 \mu \mathrm{m}$ chl $a$ standing stock were grazed by heterotrophic protists, mainly ciliates, which gave rise to seasonal variation in the abundance of different size fractions (Verity 1986). Both studies suggest strong seasonality in growth of phytoplankton $<5 \mu \mathrm{m}$ and their mainly ciliate predators. However, this smaller size fraction excludes diatoms, frequently the most productive component of estuarine plankton communities.

The goal of this study was to quantify seasonal changes in heterotrophic protist grazing rates on natural phytoplankton assemblages and describe the environmental context in which they occur. These types of data are necessary to identify associations among environmental and biological processes and may be applicable to predictive modeling studies. The research presented here was conducted in an estuary, an ecosystem where plankton populations are often more productive than in the open ocean as a result of land associations such as nutrient enrichment (Cloern \& Jassby 2008). Narragansett Bay is a well-mixed, relatively shallow (mean depth $9 \mathrm{~m}$ ), highly productive estuary located on the northeast coast of the US (Martin 1965, Borkman \& Smayda 2009a). It is the site of the longest microplankton monitoring project in the US, which commenced in the 1950 s, and which characterizes weekly plankton community composition and environmental variables (Pratt 1959, Borkman \& Smayda 2009a,b). Phytoplankton biomass in lower Narragansett Bay is frequently dominated by diatoms, often large or chainforming species (Pratt 1959, Martin 1965, Karentz \& Smayda 1998, Borkman \& Smayda 2009a). Although $>200$ species are regularly observed in Narragansett Bay samples, Skeletonema spp. often dominate summer and winter seasons, both numerically and by biomass. Abundant co-occurring phytoplankton include Thalassiosira spp., Chaetoceros spp., and nanoflagellates. In this study, protistan grazing and phytoplankton growth rates were quantified and compared to biotic and environmental drivers over the course of one seasonal cycle. We hypothesized that seasonal shifts in environmental conditions and species composition drive changes in population demographic and trophic rates.

\section{MATERIALS AND METHODS}

\section{Study site and sampling program}

Water samples were collected weekly from the surface of a station in the West Passage of Narragansett Bay $\left(41^{\circ} 34.5^{\prime} \mathrm{N}, 71^{\circ} 24.3^{\prime} \mathrm{W}\right.$, Fig. 1). Net phytoplankton growth and grazer-induced mortality rates were measured using the dilution method (Landry \& Hassett 1982) in a 2-point modification (Worden \& Binder 2003, Landry et al. 2008, Strom \& Fredrickson 2008). In total, 44 dilution experiments were conducted from 26 January 2010 through 21 February 2011. Whole surface seawater samples (WSW) were collected using a bucket and gently filtered through a $200 \mu \mathrm{m}$ mesh to remove mesozooplankton predators. Sample water was kept dark in 10 l polycarbonate carboys while in transit to the laboratory. A portion of the water was then gravity filtered through a $0.2 \mu \mathrm{m}$ filter (Pall) to yield filtered seawater (FSW). WSW was diluted with FSW to $10 \%$ WSW. Triplicates for each dilution level $(10 \%$ and $100 \%)$ were incubated in clear, 1.21 polycarbonate bottles in ambient seawater, light, and temperature for $24 \mathrm{~h}$, rotating at 2 to $3 \mathrm{rpm}$ in a flow-through seawater incubator. Chl a was extracted in triplicate when bottles were filled initially $\left(T_{0}\right)$ and in triplicate from each of the triplicate dilution bottles after $24 \mathrm{~h}\left(T_{\mathrm{F}}\right)$ for total chl a concentration measurements following Graff \& Rynearson (2011). The volume filtered ranged from 50 to $200 \mathrm{ml}$ depending on phytoplankton abundance. Acid-washed polycarbonate bottles and silicon tub- 


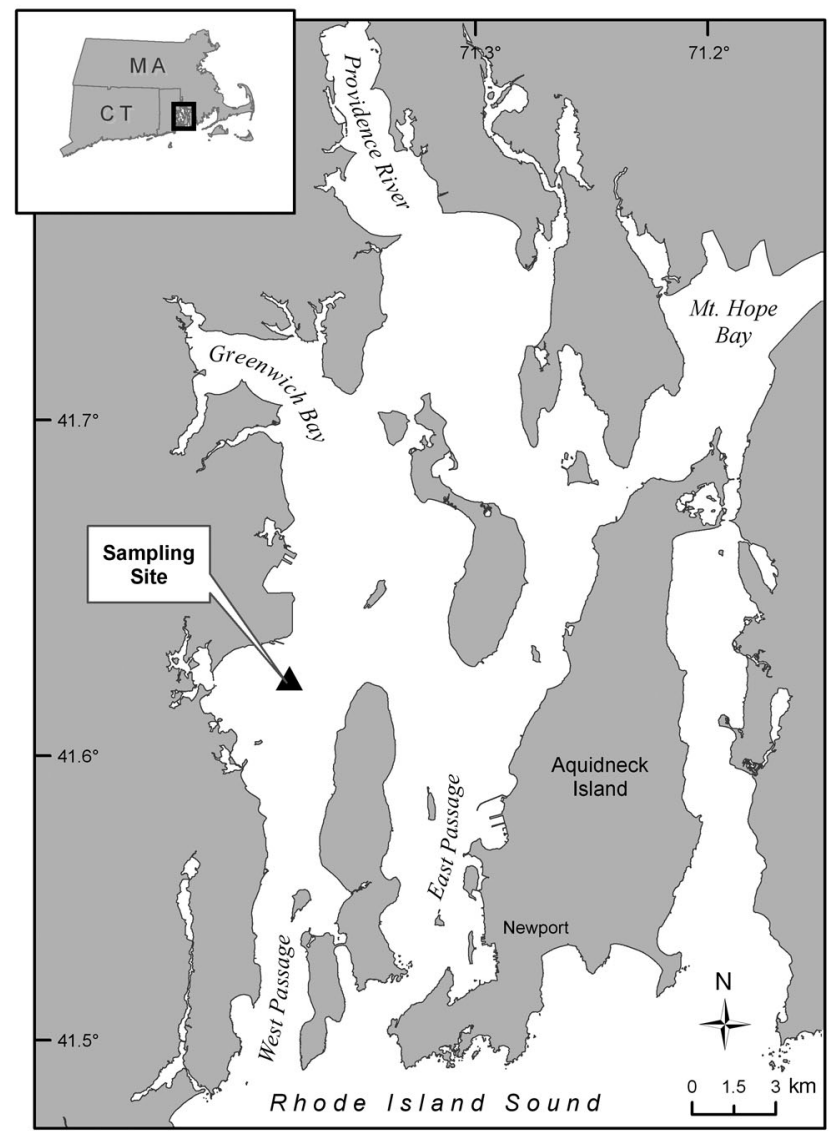

Fig. 1. Narragansett Bay, Rhode Island, USA, showing the location of the Narragansett Bay Time Series station $\left(41^{\circ} 34.5^{\prime} \mathrm{N}, 71^{\circ} 24.3^{\prime} \mathrm{W}\right)$. Map source: Rhode Island Geographic Information Systems (RIGIS), www.edc.uri.edu/ rigis/. Projection: RI Stateplane Feet; FIPS Zone: 3800; Datum NAD 83

ing were used throughout to eliminate toxicity effects on heterotrophic protists (Price et al. 1986).

Use of the dilution method to quantify grazing pressure relies on the assumptions that grazing rate is a linear function of dilution and by implication prey concentration. The 2-point modification of the dilution method employed here does not identify nonlinear feeding responses, which are observed, for example, if feeding is saturated at high prey concentrations (Gallegos 1989, Lessard \& Murrell 1998, Worden \& Binder 2003). See Moigis (2006) for a thorough comparative analysis of the effects of nonlinear feeding responses on estimates of both growth and grazing rates. The grazing rate estimates here are based on the 2-point method and provide a minimum estimate of the grazing pressure. Grazing rate $\left(g, \mathrm{~d}^{-1}\right)$ and net phytoplankton growth rate $\left(k, \mathrm{~d}^{-1}\right)$ were calculated following Worden \& Binder (2003). Net phytoplankton growth was calculated for each dilution level as $k=(1 / t) \times \ln \left(P_{t} / P_{0}\right)$, where $P_{t}$ and $P_{0}$ are the final and initial concentration of chl $a$, respectively, and $t$ is the length of incubation period in days. Previous studies have shown that the net phytoplankton growth rate for the most dilute fraction $(k$, $\mathrm{d}^{-1}$ ) was not significantly different from the instantaneous growth rate $\left(\mu, \mathrm{d}^{-1}\right)$ when comparing the 2point method with a multi-point dilution experiment (Worden \& Binder 2003, Strom \& Fredrickson 2008) and can be taken as a conservative estimate of the instantaneous growth rate (Worden \& Binder 2003). Protistan grazing rate was calculated as the difference in growth rates between the 2 dilution fractions. Samples with negative values of grazing and net phytoplankton growth were modified as in Calbet \& Landry (2004): negative phytoplankton growth rates were set to $0.01 \mathrm{~d}^{-1}$ while negative grazing rates were set to $0 \mathrm{~d}^{-1}$. Replication within experiments showed that methodological variation was low for the dilution experiments; the total coefficient of variation (CV) for both growth and grazing rates from triplicate measurements in each of the triplicate incubations with and without nutrients throughout the year was $\leq 12 \%$.

The ratio between grazing rate $\left(g, \mathrm{~d}^{-1}\right)$ and phytoplankton growth rate $\left(k, \mathrm{~d}^{-1}\right)$ was used to estimate percent primary production consumed $(\% \mathrm{PP}=g / k \times$ 100). Dates on which no significant growth was measured were not used to calculate \% PP consumed.

The use of the exponential growth equation $\left(P_{\mathrm{n}}=\right.$ $\left.P_{0} \mathrm{e}^{r t}\right)$ assumes that nutrients were not limiting during the incubation. To account for potential nutrient limitation, experiments were run both with added nutrients at saturating concentrations and without added nutrients. In summer 2010, 3 nutrient-amended experiments were conducted, in which nutrients were added to parallel experiments with triplicate bottles at both the $10 \%$ and $100 \%$ WSW levels. Evidence of significant nutrient limitation during the summer led to further nutrient-amended experiments to determine the seasonal extent of nutrient limitation. Biweekly nutrient-amended experiments were conducted from October 2010 through February 2011, although one experiment on 3 November 2010 was removed because chl a was contaminated in the non-nutrient-amended experiment. In each of these 12 experiments, triplicates of $100 \%$ and $10 \% \mathrm{WSW}$ were prepared as before with the addition of nonlimiting concentrations of nitrate and phosphate to a final concentration of 10 and $2 \mu \mathrm{mol} \mathrm{l^{-1 }}$, respectively to both the $10 \%$ and $100 \%$ WSW treatments. Nutrient concentrations for amendments were based on maximum average nutrient concentrations ob- 
served in Narragansett Bay between spring 2003 and January 2010 from the long-term phytoplankton monitoring dataset, effectively adding nutrients in excess at concentrations equal to maximum in situ observed nutrient concentrations. Samples with negative growth were included in the statistical analysis if growth rates were not limited by nutrient availability; however, samples with negative net growth were removed when no nutrient-added control was available.

\section{Historical data set}

The dilution experiments were conducted with samples from the same site as those from the Narragansett Bay Long-Term Plankton Monitoring program, initiated in 1952 (Fig. 1; Pratt 1959, Smayda 1998). Sample collection for the monitoring program includes weekly analysis of plankton community composition, size fractionated chl $a$, macronutrients, turbidity, and temperature, salinity, and dissolved oxygen measured using an in situ profiler (Yellow Springs Instrument YSI 6920 V2).

In addition to water quality analysis, local meteorological variables, such as wind velocity and precipitation (monitored at T.F. Green Airport by the National Oceanic and Atmospheric Administration, www. ncdc.noaa.gov/oa/ncdc.html), as well as irradiance (monitored by Woods Hole Oceanographic Institution, http://cis.whoi.edu/science/PO/climate) were compiled. Irradiance, measured in $\mathrm{W} \mathrm{h} \mathrm{m}^{-2}$, was used for statistical analysis. These meteorological variables, along with species-specific cell counts, temperature, salinity, and dissolved oxygen gathered for the long-term phytoplankton monitoring program, were used in the analysis of the growth and grazing rate data and to characterize seasonal trends.

\section{Plankton species composition and abundance}

For every grazing experiment, plankton community composition and numerical abundance were determined from field samples in accordance with the methods used for the long-term plankton monitoring project. A Sedgwick-Rafter (1 ml volume) chamber was used to enumerate live plankton samples to the lowest taxonomic level possible (genus or species) using a Nikon Eclipse E800 light microscope equipped with phase contrast. In order to determine initial abundance of rarer heterotrophic protists, 10 to $50 \mathrm{ml}$ of $3 \%$ Lugol's preserved samples were counted for all samples (Utermöhl 1958). Due to week-toweek variation in community composition, heterotrophic protist species were aggregated into the following groups to determine numerical dominance: loricate and aloricate ciliates, and heterotrophic dinoflagellates. While other grazer species and groups, including Ebria sp. and silicoflagellates, including Dictyocha speculum, were observed in 7 of the samples, abundances were too low $\left(\leq 7 \mathrm{ml}^{-1}\right)$ to include them in the analysis.

Carbon content was estimated for the 10 most abundant phytoplankton taxa (genus or species) present during the dilution experiment. Cells $(\mathrm{n}=$ 100 to 1000) were photographed with a microscopemounted camera (Allied Vision Technology, Stingray F-146), and the length and width for each cell were measured using ImageJ software (National Institutes of Health). Depending on cell shape, cell volume was calculated assuming a sphere, cylinder, or prolate spheroid. Cell volumes were converted to carbon content using group-specific regression equations (Menden-Deuer \& Lessard 2000).

\section{Statistical analysis}

A paired $t$-test was used to determine whether nutrient addition significantly altered phytoplankton growth rates. Linear regression analysis (Model 1) was used to describe the association between $\mathrm{chl} a$ concentration $\left(\mu \mathrm{g} \mathrm{l}^{-1}\right)$ and grazing rate $\left(\mathrm{d}^{-1}\right)$. When relating temperature $\left({ }^{\circ} \mathrm{C}\right)$ to grazing rate $\left(\mathrm{d}^{-1}\right)$, linear and non-linear regression models were applied and the one with maximum $r^{2}$ and minimal $p$ value was chosen. Principal component analysis (PCA) and multidimensional scaling (MDS) analyses were used to reduce dimensionality of multivariate environmental data or phytoplankton taxa, respectively, over the course of the year. Data points for $3 \mathrm{wk}$ representing extreme flooding and a $>10$ psu drop in salinity in March 2010 were removed, as they obscured all other relationships. This flooding event included the highest chl a concentration measured, $>29 \mu \mathrm{g} \mathrm{l}^{-1}$.

To determine seasonal patterns in phytoplankton community composition, multivariate analysis in PRIMER-E v6 (Plymouth Routines in Multivariate Ecological Research) was used. Genus/species groups were fourth-root transformed to reduce bias of plankton taxa with high cell abundances. Phytoplankton abundances were compared to season and grazing as well as environmental data. Seasons were delineated as follows: winter $=$ December, January, and February; spring = March, April, and May; sum- 
mer $=$ June, July, and August $;$ fall $=$ September, October, and November. Protistan grazing rate was partitioned into 2 groups representing the relative level of grazing; grazing rates that were $\leq 0.75 \mathrm{~d}^{-1}=$ low grazing and $>0.75 \mathrm{~d}^{-1}=$ high grazing. Variations in environmental conditions were compared to season using analysis of similarity (ANOSIM, PRIMER-E). The association between environmental data and season is described by the global $\mathrm{R}$ statistic and can range from 1 to -1 . High values of $R$, approaching 1 , indicate similarity within and separation among groups, and 0 indicates no relationship. The degree of association between non-normally distributed variables was analyzed using Spearman rank correlation. Statistical significance was assigned at $p$ values $\leq 0.05$.

\section{RESULTS}

\section{Seasonal patterns}

From January 2010 through February 2011, seasonal shifts in environmental conditions in Narragansett Bay were related to changes in temperature, irradiance, salinity, and precipitation (Fig. 2). The first 2 axes of the PCA together explained $62 \%$ of the variance of the environmental data. Over the year, surface temperature varied from 0 to $24^{\circ} \mathrm{C}$, with changes of up to $13^{\circ} \mathrm{C}$ between seasons. Irradiance ranged from 250 to $8600 \mathrm{~W} \mathrm{~h} \mathrm{~m}^{-2}$, averaging $4650 \mathrm{~W}$ $\mathrm{h} \mathrm{m}^{-2}$. Using the algorithm supplied by Keller et al. (2001), irradiance was converted to photosynthetically active radiation (PAR), which ranged from 136 to $967 \mu \mathrm{mol}$ photon $\mathrm{m}^{-2} \mathrm{~s}^{-1}$. Irradiance and temperature were highest from late spring to early fall, while dissolved oxygen at depth was lowest during the summer. Dissolved oxygen ranged from 78 to $136 \%$ saturation at the surface and 47 to $98.5 \%$ at depth.

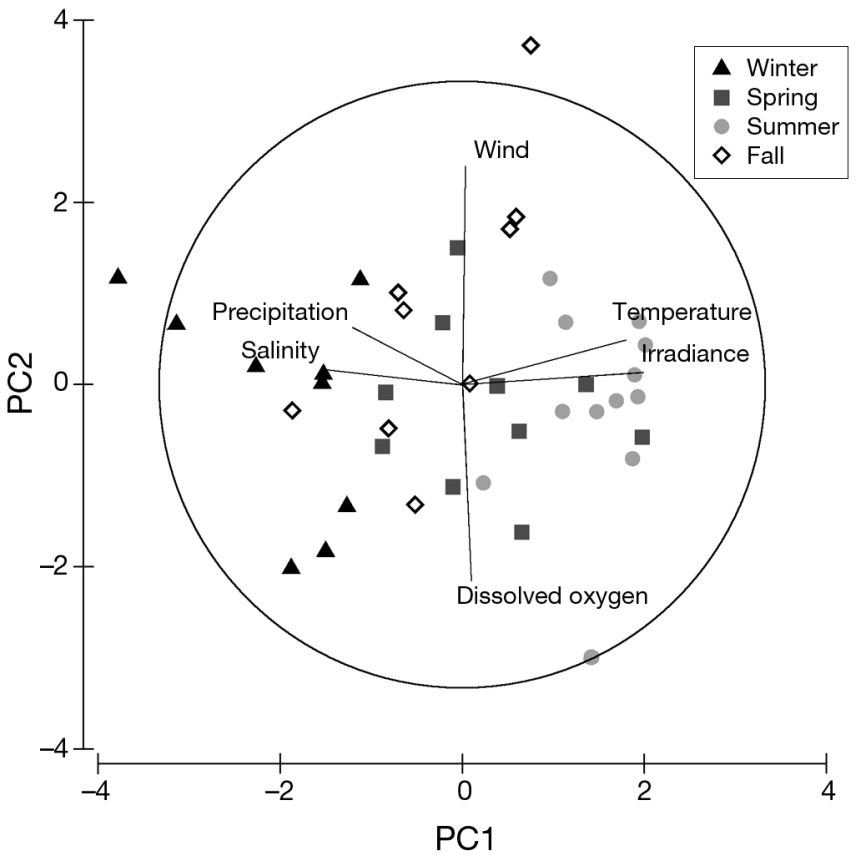

Fig. 2. Principal component analysis of environmental conditions categorized by season. Winter dates were generally associated with increased precipitation and reduced salinity, while summer was more strongly associated with increased temperature and irradiance. Fall and spring samples did not cluster as tightly as winter and summer, indicative of the considerable gradients in environmental conditions observed during seasonal transitions

Surface dissolved oxygen did not appear to be related to season, but rather to total surface phytoplankton abundance. Surface dissolved oxygen reached $>100 \%$ in all seasons, during which time total phytoplankton abundance varied broadly.

There was a clear seasonality in both phytoplankton growth and heterotrophic protist grazing rates with peaks in both processes observed in the summer. Over the course of the year, phytoplankton
Fig. 3. Rates of phytoplankton growth $\left(\mathrm{d}^{-1}\right.$, filled circles) and heterotrophic grazing rates $\left(\mathrm{d}^{-1}\right.$, open circles) for all dates with positive, or nonnutrient-limited growth from 2 February 2010 through 21 February 2011. Grey bars indicate initial chlorophyll a concentration for all dates on which a dilution experiment was conducted. Error bars are $1 \mathrm{SD}$ of triplicate measurements

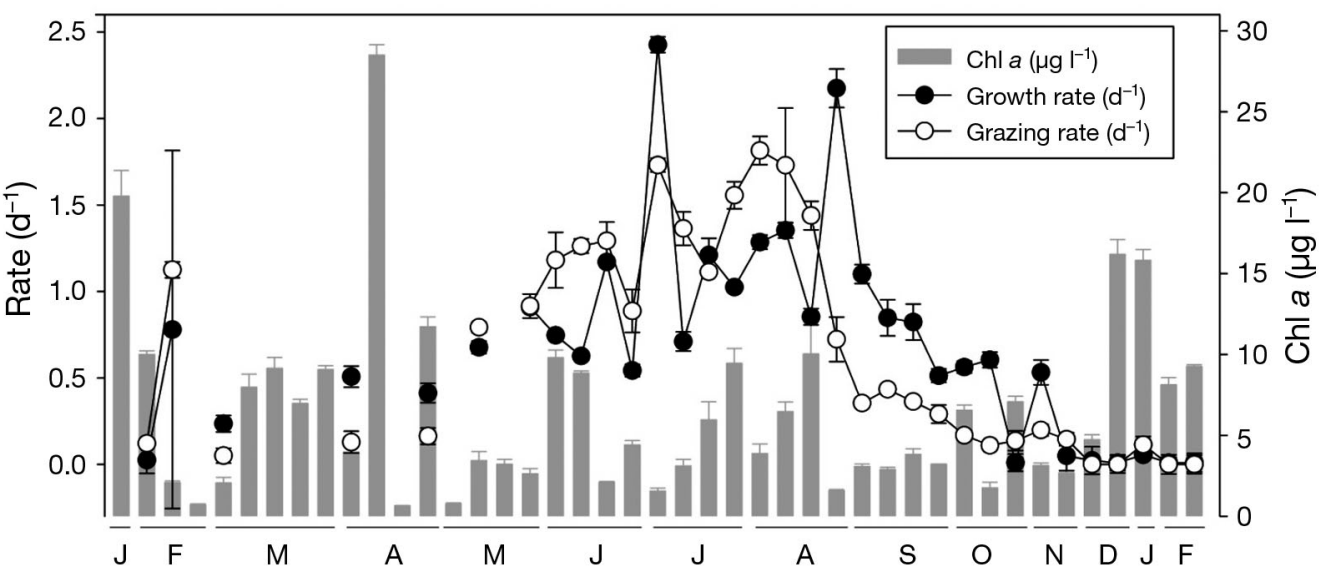


Table 1. Comparison of phytoplankton growth rates $\left(k, \mathrm{~d}^{-1}\right)$ from parallel incubations with and without added nutrients. Asterisks indicate dates with significant nutrient limitation ( $p<0.01$ ). During June and July 2010, phytoplankton growth was nutrient limited $(\mathrm{p}=0.007)$. During fall and winter 2010, negative growth rates were observed even in nutrient-amended incubations and were not significantly different from non-amended incubations $(p=0.48)$. Thus, nutrient limitation only affected phytoplankton growth rates in the summer, and other factors, such as light limitation, resulted in negative phytoplankton growth rates in the winter

\begin{tabular}{|lcc|}
\hline Date & $k$-nutrients & $k+$ nutrients \\
\hline 28 Jun $10^{*}$ & 0.54 & 2.5 \\
12 Jul 10* & 0.71 & 2.2 \\
26 Jul 10* & 1.0 & 2.9 \\
18 Oct 10 & 0.60 & 0.65 \\
16 Nov 10 & 0.53 & 0.61 \\
29 Nov 10 & 0.05 & 0.01 \\
14 Dec 10 & 0.02 & -0.04 \\
30 Dec 10 & -0.01 & -0.06 \\
11 Jan 11 & 0.05 & 0.06 \\
1 Feb 11 & -0.10 & -0.17 \\
21 Feb 11 & -0.07 & -0.10 \\
\hline
\end{tabular}

growth rates in Narragansett Bay ranged from 0.01 to $2.4 \mathrm{~d}^{-1}$ (average $0.69 \mathrm{~d}^{-1}, \mathrm{CV}=12 \%$, Fig. 3). Nonnutrient-amended phytoplankton growth rates were fastest during the summer, which was the only season in which no negative growth rates were recorded. During the fall, there was only one week with negative growth, while winter and spring both had substantial periods of negative phytoplankton growth (8 of 11 weeks and 8 of 13 weeks, respectively). On average, phytoplankton growth rates were positive for $66 \%$ of all weeks sampled. Nutrients did significantly limit phytoplankton growth during the summer $(p=0.007)$, when already substantive growth increased by an additional 3- to 4- fold after nutrient addition (Table 1). In fall and winter, nutrient addition did not significantly increase phytoplankton growth rates $(\mathrm{p}=0.48)$, and growth rates remained negative even with nutrients added.

Heterotrophic protist grazing rates were similar in magnitude and seasonal pattern to phytoplankton growth rates (Fig. 3). Heterotrophic protist grazing in non-nutrient amended experiments ranged from 0 to $1.8 \mathrm{~d}^{-1}$, with an average of $0.66 \mathrm{~d}^{-1}$ and an experimental variation of $10 \%(\mathrm{CV})$. Including grazing rates from nutrient-amended experiments for dates on which nutrients were limiting, heterotrophic protist grazing ranged from 0 to $3.7 \mathrm{~d}^{-1}$, with an average of $0.79 \mathrm{~d}^{-1}$. Of the 44 weeks sampled, $18 \%$ of experiments had non-significant grazing rates, and all instances of non-significant grazing occurred in the winter, generally when phytoplankton growth was negative. Above average grazing was observed during the summer and after the 2010 winter-spring bloom, which was observed on 26 January 2010.

\section{Fate of primary production}

The ratio of heterotrophic grazing rates to phytoplankton growth $(g / k)$ provides a measure of the $\% \mathrm{PP}$ consumed by heterotrophic protists. Between 20 and $200 \%$ (average $96 \%$ ) of PP was grazed throughout the course of the year (Fig. 4). Due to low growth and grazing rates on 2 February 2010 and 11 January 2011, variation exceeded $100 \%$ and error bars were omitted from Fig. 4. When nutrient limitation was ameliorated by nutrient addition during the summer, \%PP consumed was, at maximum, 130\%, but protistan grazing remained high relative to phytoplankton growth rates. Percent PP consumed was greatest in the summer when temperatures were

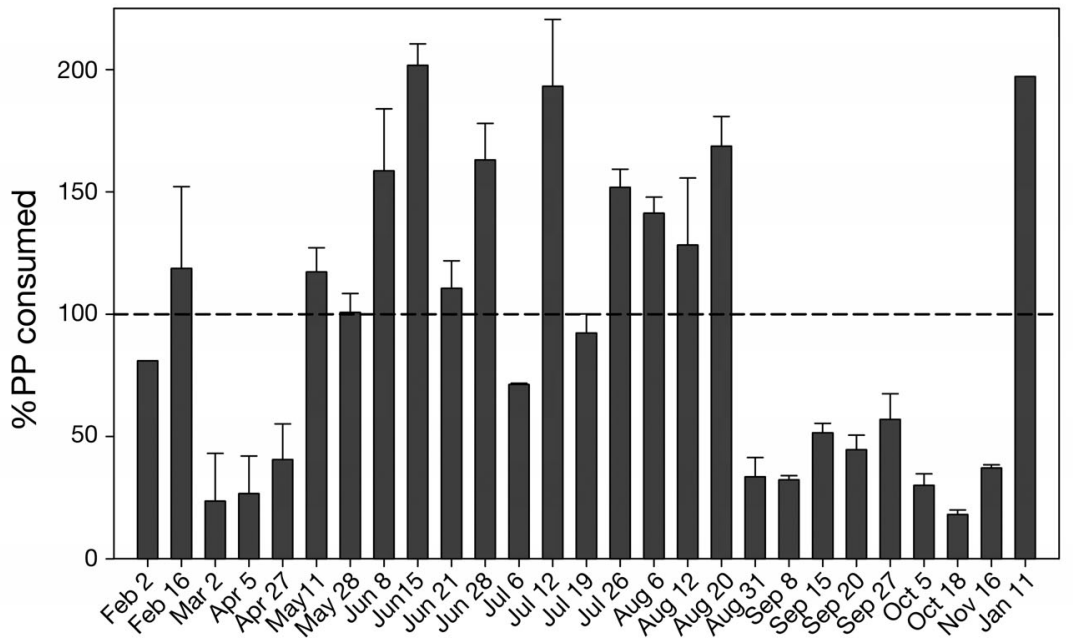

Fig. 4. Percent primary production (\%PP) consumed by heterotrophic protists from 2 February 2010 through 11 January 2011. Note axis range difference from Fig. 3. \%PP was only calculated when phytoplankton growth was significant. Error bars indicate $1 \mathrm{SD}$ of triplicate measures. Due to low growth and grazing rates on 2 February 2010 and 11 January 2011, variation exceeded $100 \%$ and error bars were omitted. The horizontal dashed line shows equal consumption and production rates 


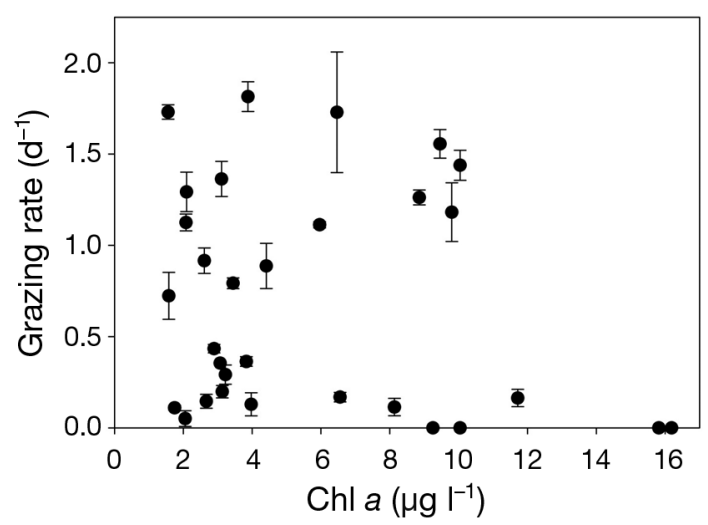

Fig. 5. Heterotrophic protist grazing rates $\left(\mathrm{d}^{-1}\right)$ versus initial chlorophyll a ( $\mathrm{chl} \mathrm{a)} \mathrm{concentration}\left(\mu \mathrm{g} \mathrm{l}^{-1}\right)$. No significant relationship was found between chl a concentration and measured grazing rates $(p=0.68)$. Error bars indicate 1 SD of triplicate measures

warmest or after peak Skeletonema spp. concentrations in the winter. During the late spring and summer, irrespective of nutrient addition, consumption largely equaled or exceeded production. During the fall and winter, with one exception, production exceeded consumption, although net growth rates were low. Although not exactly synchronized in time, higher phytoplankton standing stock was observed when grazing rates were lower and vice versa.

Bulk biomass, as measured by chl $a$, was a poor predictor of heterotrophic protist grazing pressure. Heterotrophic protist grazing rates were not significantly related to initial chl a concentrations, which ranged from 0.79 to $16.2 \mu \mathrm{g} \mathrm{l^{-1 }}$ during the course of the year (Fig. 5). The entirety of the range of measured grazing rates could be observed at low to intermediate chl a concentration.

\section{Grazing pressure correlated with predator species composition}

Variations in grazer abundance and taxonomic affiliation were reflected in grazing pressure exerted, with heterotrophic dinoflagellates associated with the greatest grazing pressure (Fig. 6). When heterotrophic dinoflagellates were numerically dominant, the average non-nutrient-amended grazing rate was $1.02 \mathrm{~d}^{-1}$, $52 \%$ higher than the overall average grazing rate of $0.79 \mathrm{~d}^{-1}$. During these periods of high grazing pressure, Protoperidinium spp. and Gyrodinium spp. had the highest annual average abundance among the heterotrophic dinoflagellates ( 400 and 500 cells l$^{-1}$ respectively). There was no association between grazing rate and abundance of aloricate ciliates. Aloricate ciliates were associated equally frequently with above and below average grazing rates. The average grazing rate when aloricate ciliates were dominant was $0.70 \mathrm{~d}^{-1}$, nearly identical to the overall annual average grazing rate of $0.79 \mathrm{~d}^{-1}$. Loricate ciliates were clearly associated with below average grazing rates. When loricate ciliates were dominant, below average grazing rates were observed $83 \%$ of the time. Average grazing rate was $0.35 \mathrm{~d}^{-1}$ when loricate ciliates were numerically dominant. These shifts in grazing pressure due to shifts in taxonomy also had a seasonal component. Loricate ciliates tended to dominate during the spring and fall, while heterotrophic dinoflagellates were more abundant during the summer.

There was a significant relationship between temperature and grazing rate $(\mathrm{p}<0.001)$ with fastest grazing rates observed at the highest water temperatures (Fig. 7). The fastest grazing rates occurred when temperatures were warmest. A noteworthy exception occurred in February 2010, following the winter-spring bloom, when temperature was $1.38^{\circ} \mathrm{C}$ and grazing rate reached a seasonal maximum of $1.13 \mathrm{~d}^{-1}$. Overall, most incidences of high grazing rate occurred, irrespective of season or water temperature, when the phytoplankton community composition resembled summer samples most closely.

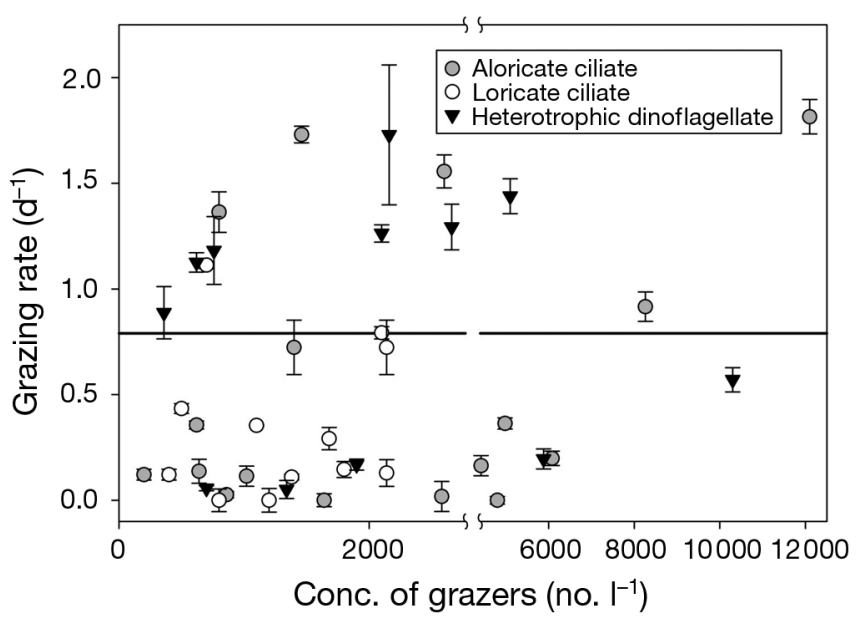

Fig. 6. Heterotrophic protist grazing rate $\left(\mathrm{d}^{-1}\right)$ versus numerical abundance of aloricate ciliates, loricate ciliates, and heterotrophic dinoflagellates. Error bars represent 1 SD of triplicate measures. Solid line represents average grazing rates for all dates sampled. One datum of $>3 \times 10^{4}$ aloricate ciliates $\mathrm{l}^{-1}$ and a grazing rate of $0 \mathrm{~d}^{-1}$ was omitted from the graph. When loricate ciliates were numerically dominant, total measured grazing rate was below average ( $83 \%$ of measurements). Aloricate ciliates were equally frequently associated with above and below average grazing rates (50\% of measurements). Heterotrophic dinoflagellate numerical dominance was associated with above average grazing rates in $78 \%$ of the cases 


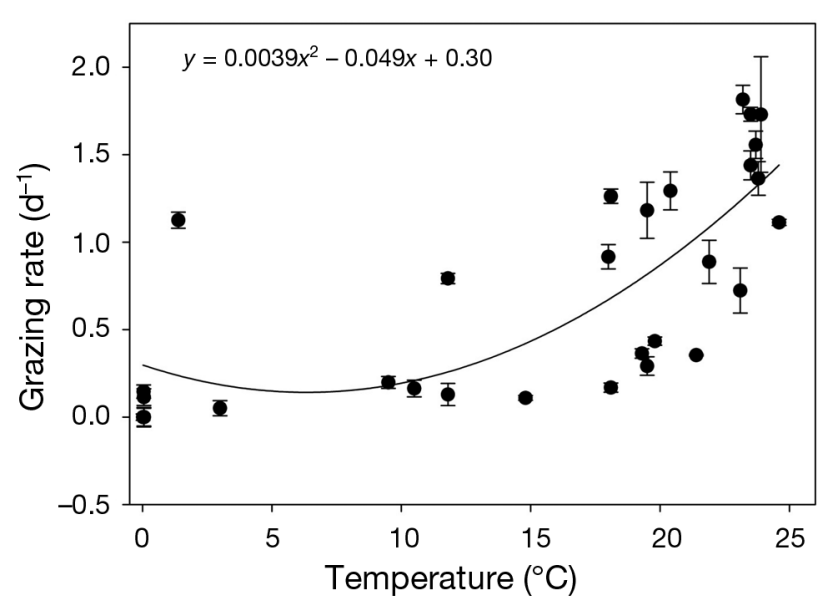

Fig. 7. Heterotrophic grazing rate $\left(\mathrm{d}^{-1}\right)$ versus surface temperature for all weeks with positive or non-nutrient-limited phytoplankton growth rates. Error bars represent 1 SD of triplicate measures. Only 8 of 17 experiments conducted below $10^{\circ} \mathrm{C}$ were plotted because phytoplankton growth rates were non-significant. There was a significant relationship between temperature and grazing rate $(\mathrm{p}<0.001$, $\left.r^{2}=0.53\right)$ with the highest grazing rates observed at the highest water temperatures. However, a high grazing rate was observed even at near freezing temperatures when phytoplankton community composition resembled summer community composition (see Fig. 8 and 'Results')

\section{Seasonal patterns in community composition}

When relating environmental conditions to phytoplankton community composition, temperature appeared to be most strongly correlated with changes in species composition (Spearman correlation coefficient $\rho=0.29, p=0.001)$. Weekly species counts showed that diatoms were the most numerically abundant phytoplankton, averaging $67 \%$ of total cell abundance. Skeletonema spp. were present year round, with peaks in abundance in the winter and summer (Table 2). Flagellates were also abundant year round, though numerical abundance was greatest during the summer and fall. Thalassiosira nordenskioeldii and Heterocapsa cf. triquetra were abundant during the winter and early spring, when temperatures were lower (ranging from 0.5 to $12^{\circ} \mathrm{C}$ ). Leptocylindrus minimus and Cylindrotheca closterium were abundant during the summer when temperatures were between 15 and $24^{\circ} \mathrm{C}$, although these species were present even at $0.5^{\circ} \mathrm{C}$. Chaetoceros debilis dominated biomass during the late fall.

Clear seasonal shifts in phytoplankton community composition were evident from the weekly plankton abundance data (Fig. 8). Based on an ANOSIM, phytoplankton community composition was strongly associated with season based on a comparison of carbon content of the 10 most abundant phytoplankton species (Table 3). Changes in the abundance of Skeletonema spp. were the most significant drivers of changes of phytoplankton community composition. The composition of the phytoplankton community was most consistent in winter and spring, while spring and summer were most different from one another $(\mathrm{p}=0.001)$. The phytoplankton community during summer differed most strongly from all other seasons. These seasonal phytoplankton associations were found irrespective of whether biomass or numerical abundance of phytoplankton was used as a metric. The only difference between the 2 analytical approaches was that the global R-statistic was on average 1.5 times greater when the analysis included all 58 taxa rather than the carbon content of the 10 most abundant species.

\section{DISCUSSION}

It has been estimated that, on average, heterotrophic protists graze over half of daily global primary production (Calbet \& Landry 2004). In this and in many previous studies, protistan grazing rates fre-

Table 2. Seasonal average of carbon content $\left(\mu \mathrm{g}^{-1}\right)$ for 10 dominant plankton species observed throughout the course of the year. The largest total biomass was observed during the winter when large cells such as Heterocapsa cf. triquetra and Thalassiosira nordenskioeldii were most abundant

\begin{tabular}{|lcccc|}
\hline & Winter & Spring & Summer & Fall \\
\hline Chaetoceros debilis & 0 & 0 & 52.8 & 136 \\
Chaetoceros socialis & 0 & 41.1 & 7.83 & 24.6 \\
$\begin{array}{l}\text { Chaetoceros spp. } \\
\text { Cylindrotheca }\end{array}$ & 6.57 & 157 & 33.9 & 12.1 \\
$\quad$ closterium & $2.68 \times 10^{-2}$ & $4.29 \times 10^{-2}$ & 7.61 & $7.13 \times 10^{-1}$ \\
Unknown flagellate & 9.27 & 2.49 & 18.7 & 11.3 \\
$\begin{array}{l}\text { Heterocapsa cf. } \\
\text { triquetra }\end{array}$ & 992 & 15.9 & 0 & 0 \\
$\begin{array}{l}\text { Leptocylindrus } \\
\text { minimus }\end{array}$ & 5.31 & 0 & 5.15 & 1.72 \\
$\begin{array}{l}\text { Skeletonema spp. } \\
\text { Thalassiosira } \\
\text { nordenskioeldii }\end{array}$ & 126 & 19.9 & 166 & 30.2 \\
Thalassiosira spp. & 54.3 & 331 & 0 & 0 \\
& 6.42 & 4.94 & 238 & 165 \\
\hline
\end{tabular}




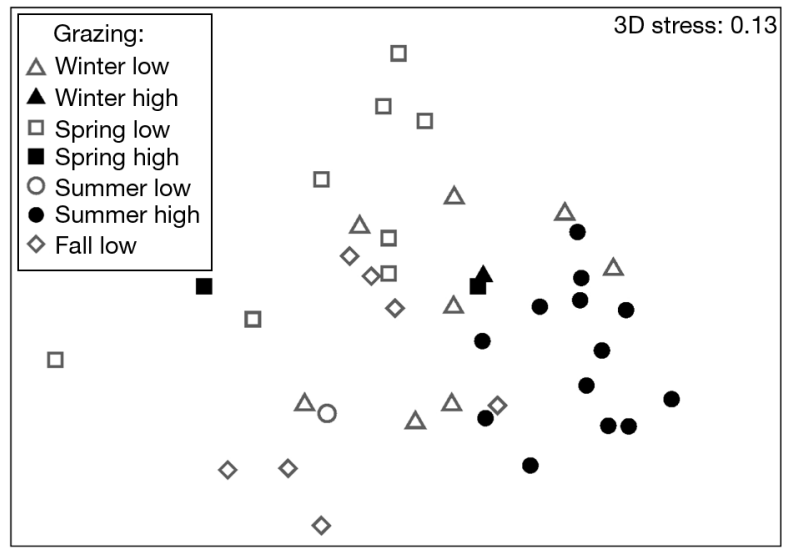

Fig. 8. Multidimensional scaling (MDS) analysis of phytoplankton community composition during the 4 seasons. Shown is a 2D rendition of a 3D MDS analysis. Samples with similar community composition are plotted in close proximity. Average grazing pressure measured during that season is indicated as high ( $>0.75 \mathrm{~d}^{-1}$, filled symbols) and low $\left(<0.75 \mathrm{~d}^{-1}\right.$, open symbols). Phytoplankton community composition for summer dates were most closely related to one another and associated with the highest grazing pressure. It is noteworthy that phytoplankton community composition for one winter and spring sample with high grazing each more closely resembled summer community composition, suggesting that phytoplankton community composition played a substantial role in driving observed grazing rates

Table 3. Similarity among phytoplankton community composition compared across seasons (ANOSIM). Analysis was based on abundance of the 10 most abundant plankton species measured as biomass (carbon content, $\mu \mathrm{g} \mathrm{l}^{-1}$ ). Community composition from any given season was significantly different from all other seasons $\left({ }^{*} p<0.05,{ }^{* *} p \leq 0.001\right)$ except between winter and spring $(p=0.1)$. The most extreme change in plankton community composition was observed between spring and summer

\begin{tabular}{|ll|}
\hline Groups & Global R \\
\hline Spring, Summer & $0.55^{* *}$ \\
Summer, Winter & $0.51^{* *}$ \\
Summer, Fall & $0.35^{*}$ \\
Winter, Fall & $0.40^{* *}$ \\
Spring, Fall & $0.29^{*}$ \\
Winter, Spring & 0.10 \\
\hline
\end{tabular}

quently and on average exceeded phytoplankton growth rates, which suggests a mechanism for the majority of phytoplankton mortality. However, it is still unclear what factors determine the magnitude of protistan grazing pressure. There was no relationship between initial chl a concentrations in the dilution experiments and the measured grazing rates, which has been observed previously (Strom et al. 2001, Sherr et al. 2009, Menden-Deuer \& Fredrickson 2010). In con- trast, Verity (1986) found a strong positive correlation between grazing and chl a concentration at the same site when he investigated the grazing of ciliates on the $<5 \mu \mathrm{m}$ chl a size fraction. It is likely that the excellent agreement observed by Verity (1986) resulted from a suitable matching of predator and prey types in the appropriate size spectrum (i.e. ciliates and $<5 \mu \mathrm{m}$ chl a size fraction), whereas our study measured grazing by all protistan predator types on the whole phytoplankton community. Irigoien et al. (2005) suggested differential algal palatability, due to specific defenses or morphological incompatibility as a possible mechanism for a mismatch in the relationship between predation and apparent availability in biomass. In most instances, chl a is likely a poor predictor of realized grazing rate because chl a does not reflect the degree of palatability of a specific prey species to predators. Chl a concentration may only yield strong predictive power for the ultimate grazing rate when well-matched predator-prey assemblages are dominant or abundant.

Protistan grazing was not related to bulk biomass measured by chl $a$, but it was related to the abundance of specific phytoplankton species. When protistan grazing rates were high $\left(>0.75 \mathrm{~d}^{-1}\right)$, abundances of the chain-forming diatoms Skeletonema spp., Chaetoceros spp., and Leptocylindrus minimus were typically 28 times greater than when grazing rates were $<0.5 \mathrm{~d}^{-1}$. In particular, there was a strong relation between protistan grazing and Skeletonema spp., the dominant bloom-forming diatom in lower Narragansett Bay. Over the course of the study, there were 5 dates on which Skeletonema spp. abundance was greater than $1 \times 10^{7}$ cells $1^{-1}$. With the exception of fall, these high abundances of Skeletonema spp. all coincided with high grazing rates $\left(>0.75 \mathrm{~d}^{-1}\right)$. These high grazing rates agree with work by Jeong et al. (2004) which has shown that grazing by a thecate dinoflagellate on $S$. costatum exceeded grazing by the copepod genus Arcatia spp. by up to 17 -fold. The increase in protistan grazing was delayed after the 2010 winter bloom when Skeletonema spp. were the only numerically abundant species and protistan grazing rates increased by $1 \mathrm{~d}^{-1}, 4 \mathrm{wk}$ after the peak of the bloom. A similar delayed response in grazing rates has been observed in other cold water conditions (Levinsen et al. 2000).

Other studies have found that protistan grazing rates often exceeded phytoplankton growth rates when the diatoms Chaetoceros spp., Thalassiosira spp., and Skeletonema spp. bloomed (Bec et al. 2005, Leising et al. 2005). In our study, phytoplankton species composition was also a strong predictor of protis- 
tan grazing pressure. High grazing rates that coincide with dominance of specific species, rather than absolute bulk prey concentrations (e.g. chl a) imply that abundance of a specific prey type is a more appropriate predictor of grazing pressure rather than total phytoplankton biomass.

It is noteworthy that we observed the most intense grazing pressure when heterotrophic dinoflagellates were abundant along with large $(>20 \mu \mathrm{m})$ diatoms. This is a result well supported by numerous prior studies (Jeong et al. 2004, Saito et al. 2006, Strom et al. 2007) and reviewed by Sherr \& Sherr (2007). Our results further support the notion that modeling efforts of planktonic trophic and demographic rates urgently need to refrain from simple size-based classifications and shift towards incorporating empirically observed linkages between predators and prey types, including the significant trophic transfer between heterotrophic dinoflagellates and diatoms.

Protistan grazing rates were lower than average when species including the diatoms Chaetoceros socialis, Thalassiosira nordenskioeldii and the dinoflagellate Heterocapsa cf. triquetra were numerically abundant. $H$. triquetra is a common dinoflagellate in estuarine systems and has been associated with low protistan grazing pressure (Litaker et al. 2002), which was also the case in this study. C. socialis forms large colonies, and T. nordenskioeldii is a large chainforming diatom with chitinous threads, perhaps making these species difficult for heterotrophic protists to ingest. Chl a concentration is expected to be a poor predictor of grazing pressure when these types of phytoplankton dominate. Overall, these results suggest that community composition rather than total chl a concentration would ultimately hold greater predictive power of the magnitude of grazing pressure.

Variability in the abundance of grazer types was another strong correlate of the magnitude of grazing rate measured. Biomass of grazers was not directly measured for this study, but the abundance of grazers in several categories was enumerated. Prior analyses have shown that rarer, large species often contribute disproportionately to grazing pressure and are poorly represented in numerical abundance measures (Sherr \& Sherr 2007). Therefore, the contribution of larger heterotrophic protist species, particularly heterotrophic dinoflagellates and aloricate ciliates, to overall grazing pressure may even be underestimated in this study. Heterotrophic dinoflagellates may be especially successful grazers in Narragansett Bay as they are known to feed preferentially on large phytoplankton (Jacobson \& Anderson 1986, Buskey 1997, Jeong et al. 2004, Menden-Deuer et al. 2005, Sherr \& Sherr 2007). Loricate ciliates do not graze effectively on large diatoms (Verity \& Villareal 1986, Löder et al. 2011). Instead, Verity (1986) found that loricate ciliates were the dominant grazers on the $<5 \mu \mathrm{m}$ size fraction in Narragansett Bay. Similarly, Löder et al. (2011) reported that ciliate predators had a narrower prey-size spectrum and their population dynamics were more directly affected by prey type availability than those of heterotrophic dinoflagellates, which had a broader prey-size spectrum. In this study, taxonomic analysis revealed important food web dynamics, including that dinoflagellate grazers were associated with a greater community grazing impact. These results suggest a specialization among predator types with respect to prey types that may be useful in linking species composition to grazing pressure. Grazing rates may depend upon grazer group present and the ability of grazers to successfully prey on the phytoplankton community available.

Our observations of heterotrophic dinoflagellates exerting disproportional grazing pressure contradict a recent critique of the dilution method by Dolan \& McKeon (2005). Although we are in agreement with the authors that results from the dilution method need to be critically evaluated, we believe results gathered, especially in a relative and comparative sense, provide useful insights. Dolan \& McKeon (2005) suggested that ciliate grazers present a reasonable proxy for total grazing pressure and that grazing rates can easily be overestimated because of differential survival of ciliate grazers as a function of dilution, ranging from ciliate predator growth in the undiluted treatment to ciliate starvation in highly dilute samples, $10 \%$ in our case. Although such differential survival and consequent overestimates of grazing have been observed in oligotrophic waters of the Mediterranean (Dolan \& McKeon 2005) and a eutrophic estuary (Dolan et al. 2000), we do not believe that this critique applies to our results, which clearly showed a linkage in high grazing rates when phytoplankton communities were dominated by large diatoms and accompanied by heterotrophic dinoflagellates. Moreover, in our study, ciliate predators were associated with low grazing pressure, ranging from average to below average grazing rates, and thus ciliates are unlikely a reasonable proxy of grazer concentration and predation pressure.

Environmental conditions were suitable for Skeletonema spp. bloom formation during both winters sampled. Borkman \& Smayda (2009a) found that winters with bright, cold, and windy conditions as well as low abundance of the copepod Acartia hudsonica 
were conducive to Skeletonema spp. bloom formation. In both 2010 and 2011, these conditions were present at the initiation of the Skeletonema spp. bloom; however, bloom magnitude, quantified by both cell abundances and chl a concentration, and duration differed in each year. In 2010, there was a large, short-lived high abundance of Skeletonema spp., but growth appeared to be negative, suggesting that the experiment may have been conducted after the initiation of the bloom when phytoplankton growth was no longer positive. In winter 2010/2011, chl a showed a long, broad bloom which reached above $15 \mathrm{\mu g} \mathrm{l}^{-1}$ on 30 December 2010 as a result of high Heterocapsa cf. triquetra abundance. Subsequently there was a shift in the dominant species from $H$. cf. triquetra to Skeletonema spp., indicative of the characteristic winter-spring Skeletonema spp. bloom in early January. The shift to Skeletonema spp. dominance was observed concomitantly with the only positive phytoplankton growth rate observed in winter 2011. It is noteworthy that phytoplankton growth rate was only slight $\left(0.05 \mathrm{~d}^{-1}\right)$, suggesting growth need not be very large in order to reach bloom concentrations. Skeletonema spp. winter-spring bloom formation has been attributed great importance as an environmental indicator in Narragansett Bay (Oviatt et al. 2002). The winter Skeletonema spp. blooms in 2010 and 2011 likely occurred as a result of favorable environmental conditions which have not occurred with consistency for many years due to a negative NAO (North Atlantic Oscillation) (Oviatt et al. 2002, Borkman \& Smayda 2009a). With the recent shift in NAO from a positive to a negative phase, we predict that the yearly average of Skeletonema spp. (likely to be $>2000$ cells ml$^{-1}$ ) will increase from those observed during the positive phase, which may ultimately result in increased grazing by heterotrophic protists.

Seasonal patterns were observed in multiple biotic and abiotic measurements, particularly in temperature and phytoplankton community composition. Phytoplankton growth rates in Narragansett Bay were greatest during the summer despite significant nutrient limitation. Grazing by heterotrophic protists was also greatest during the summer, with grazing rates of up to $3.7 \mathrm{~d}^{-1}$ or $130 \%$ of the non-nutrientlimited standing stock. This begs the question: how does phytoplankton biomass persist and form blooms despite nutrient limitation and substantial grazing pressure? This study may have overestimated the realized protistan grazing pressure because metazoan predators were deliberately excluded through sieving. Martin (1970) found that zooplankton in Nar- ragansett Bay $(>160 \mu \mathrm{m})$ exerted significant grazing pressure during spring and early summer. The widely observed preference of many copepod species for heterotrophic protist prey over phytoplankton may result in reduced protistan abundance and thus reduced grazing pressure on phytoplankton (Levinsen et al. 2000). Additionally, we suggest that the rate of nutrient recycling within the system, particularly by non-metazoan grazers, was great enough to continually stimulate phytoplankton growth. While smaller flagellates $(<10 \mu \mathrm{m})$ tend to dominate nutrient regeneration, heterotrophic protists do regenerate nutrients to a greater degree than do copepods (Glibert et al. 1992, Miller et al. 1995). Sustained grazing by heterotrophic protists and large numbers of flagellates during the nutrient-limited summer months may have rapidly recycled nutrients, allowing phytoplankton growth to persist. In the absence of protistan grazing, nutrients may be lost due to export through sinking of phytoplankton aggregates or copepod fecal pellets (Legendre \& Rassoulzadegan 1996, Turner 2002). This differential between retention of nutrients in the system during times of higher protistan herbivory and bacterivory may lead to greater persistence of a bloom, especially when nutrients are limiting phytoplankton growth.

This study was characterized by a high sampling frequency and resolution. A total of 44 dilution experiments were conducted either weekly or 2weekly over the course of $12 \mathrm{mo}$, which, with the exception of Verity (1986), exceeds many prior studies in temporal resolution. Despite this exceptionally high resolution, we were unable to predict measured chl a from phytoplankton growth and protistan grazing rates. The trophic and demographic rates only coarsely matched primary productivity dynamics measured by changes in total chl a between weeks. Most notably, the large blooms of Skeletonema spp. observed in January of both years cannot easily be explained by the very low growth rates measured $\left(\leq 0.05 \mathrm{~d}^{-1}\right)$. Considering Skeletonema spp. abundances increased from 410 cells ml ${ }^{-1}$ on 30 December 2010 to 2400 cells ml $^{-1}$ on 11 January 2011, or 6-fold, 2.5 population doublings without concurrent losses were necessary to produce the observed bloom. This increase in biomass is equivalent to and could result from a moderate continuous growth at an average rate of $0.16 \mathrm{~d}^{-1}$ over the course of $11 \mathrm{~d}$. Since plankton demographic processes occur on the order of hours to days, it is possible that the intervening times between samplings may have included periods of suitable conditions for Skeletonema spp. growth and permitted the build-up of the Skeletonema spp. 
bloom observed. Moreover, heterotrophic dinoflagellates, the predominant grazers on diatoms during our study, were absent for the period preceding the bloom. These considerations are based on the assumption that phytoplankton distributions are homogeneous in Narragansett Bay, which is not the case (Oviatt et al. 2002). A Lagrangian study, such as the one used by Landry et al. (2008), could assist in resolving the short-term population dynamics of phytoplankton in this system. The discrepancy between measured rates and observed population abundances indicates that despite the comparatively high frequency of sampling and large number of total experiments, short-term plankton population dynamics could not be derived from rate measurements made at weekly intervals. However, the sampling frequency was sufficient to determine seasonal dynamics.

Our study showed a significant seasonal change in a host of environmental and biotic factors. Protistan grazing and phytoplankton growth were greatest during the summer, and both rates were much reduced in the winter and spring. Many studies have found a pronounced seasonality in grazing rates, including increased protistan grazing rates during the warmest seasons and reduced protistan grazing and phytoplankton growth in winter/colder months (Palomares-Garcia et al. 2006, Kim et al. 2007, Calbet et al. 2008, Ara \& Hiromi 2009). Such a temperaturedependent shift in grazing has also been observed for Arcatia spp. in Narragansett Bay, with rates increasing 4- to 6-fold from winter/spring to summer/fall (Deason 1980). It has been suggested that low temperatures cause a more substantial reduction in heterotrophic protist growth rates than phytoplankton growth rates (Rose \& Caron 2007). However, substantial protistan grazing and phytoplankton growth can occur even when temperatures are low (Levinsen et al. 2000, Putland 2000). Sherr et al. (2009) measured substantive phytoplankton growth and heterotrophic protist grazing rates at near freezing temperatures in the Western Arctic Ocean, and our results also recorded substantive grazing at $1.3^{\circ} \mathrm{C}$. Prior reports of low grazing rates at low temperatures (Caron et al. 2000, Sherr et al. 2009, Calbet et al. 2011) may have been the result of a seasonal mismatch in predators and prey, rather than a physiological effect of temperature. Our observation supports that hypothesis, as grazing in the winter was substantial when the phytoplankton community most closely resembled the summer time community.

The increase in temperature associated with increased protistan grazing rates was concurrent with a shift in predator and prey species community compositions. Similarly, Rose et al. (2009) found that a temperature increase not only resulted in a change in protistan community composition and physiology but also influenced the phytoplankton community composition. The observed similarity of phytoplankton community composition whenever grazing rates were $>0.75 \mathrm{~d}^{-1}$ is especially indicative of the importance of plankton community composition. With the exception of one high grazing rate after the winterspring bloom and two in the spring, all high grazing rates occurred in summer. Therefore, the relative effects of temperature and species composition could not be statistically separated to distinguish which one was the driving factor or whether both were equally important. Manipulative experiments altering community composition and temperature would be required to resolve this issue, provided the physiological tolerance of the species permitted successful experiments. Temperature responses of organisms need to be examined taking the physiological range of species and resultant shifts in community composition into account. Therefore, temperature alone without consideration of community composition may not have the strong scaling, $Q_{10}$ type effect that is commonly assumed (e.g. Hansen et al. 1997) and should be further investigated before extensive use to parameterize trophic and demographic rates.

In summary, high frequency analysis of plankton population dynamics concurrent with biological and environmental data allowed us to identify the importance of temperature and predominantly predator and prey species composition as strong correlates of predation pressure. Gathering this type of information, e.g. through automated in situ technology (Olson \& Sosik 2007, Sosik \& Olson 2007) may help improve our predictive ability of phytoplankton population dynamics and derivative metrics, including rates of primary and export production.

Acknowledgements. This paper is presented on the occasion of Professor Theodore Smayda's 80th birthday, to honor his invaluable contributions to the study of plankton ecology in general and in Narragansett Bay specifically. We thank T. Puckett, captain of the RV 'Cap'n Burt', and Narragansett Bay Long-Term Monitoring Program director T. Rynearson, Graduate School of Oceanography, University of Rhode Island (URI). Carol Gibson generated the Map of Narragansett Bay. This manuscript was greatly improved by reviews from T. Rynearson, M. Gomez-Chiarri, and 4 anonymous reviewers. Funding for this project was provided by URI in support of the Narragansett Bay Long-Term Monitoring Program, National Science Foundation EPSCoR grant no. EPS-1004057 as well as the Office of Naval Research (N000141010124) to S.M.D. 


\section{LITERATURE CITED}

Ara K, Hiromi J (2009) Seasonal variability in plankton food web structure and trophodynamics in the neritic area of Sagami Bay, Japan. J Oceanogr 65:757-779

Bec B, Husseini-Ratrema J, Collos Y, Souchu P, Vaquer A (2005) Phytoplankton seasonal dynamics in a Mediterranean coastal lagoon: emphasis on the picoeukaryote community. J Plankton Res 27:881-894

> Behrenfeld MJ (2010) Abandoning Sverdrup's Critical Depth Hypothesis on phytoplankton blooms. Ecology 91:977-989

> Borkman DG, Smayda T (2009a) Multidecadal (1959-1997) changes in Skeletonema abundance and seasonal bloom patterns in Narragansett Bay, Rhode Island, USA. J Sea Res 61:84-94

Borkman DG, Smayda TJ (2009b) Gulf Stream position and winter NAO as drivers of long-term variations in the bloom phenology of the diatom Skeletonema costatum 'species-complex' in Narragansett Bay, RI, USA. J Plankton Res 31:1407-1425

> Buskey EJ (1997) Behavioral components of feeding selectivity of the heterotrophic dinoflagellate Protoperidinium pellucidum. Mar Ecol Prog Ser 153:77-89

Calbet A, Landry MR (2004) Phytoplankton growth, microzooplankton grazing, and carbon cycling in marine systems. Limnol Oceanogr 49:51-57

> Calbet A, Trepat I, Almeda R, Salo V and others (2008) Impact of micro- and nanograzers on phytoplankton assessed by standard and size-fractionated dilution grazing experiments. Aquat Microb Ecol 50:145-156

Calbet A, Saiz E, Almeda R, Movilla JI, Alcaraz M (2011) Low microzooplankton grazing rates in the Arctic Ocean during a Phaeocystis pouchetii bloom (Summer 2007): fact or artifact of the dilution technique? J Plankton Res 33:687-701

> Caron DA, Dennett MR, Lonsdale DJ, Moran DM, Shalapyonok L (2000) Microzooplankton herbivory in the Ross Sea, Antarctica. Deep-Sea Res II 47:3249-3272

> Cloern JE, Jassby AD (2008) Complex seasonal patterns of primary producers at the land-sea interface. Ecol Lett 11: 1294-1303

> Deason EE (1980) Grazing of Acartia hudsonica (A. clausi) on Skeletonema costatum in Narragansett Bay (USA): influence of food concentration and temperature. Mar Biol 60:101-113

> Dolan JR, McKeon K (2005) The reliability of grazing rate estimates from dilution experiments: Have we over-estimated rates of organic carbon consumption by microzooplankton? Ocean Sci 1:1-7

> Dolan JR, Gallegos CL, Moigis A (2000) Dilution effects on microzooplankton in dilution grazing experiments. Mar Ecol Prog Ser 200:127-139

Field CB, Behrenfeld MJ, Randerson JT, Falkowski P (1998) Primary production of the biosphere: integrating terrestrial and oceanic components. Science 281:237-240

Franks PJS (2001) Phytoplankton blooms in a fluctuating environment: the roles of plankton response time scales and grazing. J Plankton Res 23:1433-1441

Gallegos CL (1989) Microplankton grazing on phytoplankton in the Rhode River, Maryland: non-linear feeding kinetics. Mar Ecol Prog Ser 57:23-33

Glibert PM, Miller CA, Garside C, Roman MR, McManus GB (1992) $\mathrm{NH}_{4}{ }^{+}$regeneration and grazing: interdependent processes in size-fractionated ${ }^{15} \mathrm{NH}_{4}^{+}$experiments.
Mar Ecol Prog Ser 82:65-74

> Graff J, Rynearson T (2011) Extraction method influences the recovery of phytoplankton pigments from natural assemblages. Limnol Oceanogr Methods 9:129-139

> Hansen PJ, Bjørnsen PK, Hansen BW (1997) Zooplankton grazing and growth: scaling within the $2-2,000 \mu \mathrm{m}$ body size range. Limnol Oceanogr 42:687-704

Irigoien X, Flynn KJ, Harris R (2005) Phytoplankton blooms: a 'loophole' in microzooplankton grazing impact? J Plankton Res 27:313-321

Jacobson DM, Anderson DM (1986) Thecate heterotrophic dinoflagellates-feeding behavior and mechanisms. J Phycol 22:249-258

Jeong H, Yoo Y, Kim S, Kang N (2004) Feeding by the heterotrophic dinoflagellate Protoperidinium bipes on the diatom Skeletonema costatum. Aquat Microb Ecol 36:171-179

Karentz D, Smayda TJ (1998) Temporal patterns and variations in phytoplankton community organization and abundance in Narragansett Bay during 1959-1980. J Plankton Res 20:145-168

Keller AA, Taylor C, Oviatt C, Dorrington T, Holcombe G, Reed L (2001) Phytoplankton production patterns in Massachusetts Bay and the absence of the 1998 winterspring bloom. Mar Biol 138:1051-1062

Kim S, Park MG, Moon C, Shin K, Chang M (2007) Seasonal variations in phytoplankton growth and microzooplankton grazing in a temperate coastal embayment, Korea. Estuar Coast Shelf Sci 71:159-169

> Landry MR, Hassett RP (1982) Estimating the grazing impact of marine micro-zooplankton. Mar Biol 67: 283-288

> Landry MR, Decima M, Simmons MP, Hannides CCS, Daniels E (2008) Mesozooplankton biomass and grazing responses to Cyclone Opal, a subtropical mesoscale eddy. Deep-Sea Res II 55:1378-1388

> Legendre L, Rassoulzadegan F (1996) Food-web mediated export of biogenic carbon in oceans: hydrodynamic control. Mar Ecol Prog Ser 145:179-193

> Leising AW, Horner R, Pierson JJ, Postel J, Halsband-Lenk C (2005) The balance between microzooplankton grazing and phytoplankton growth in a highly productive estuarine fjord. Prog Oceanogr 67:366-383

Lessard EJ, Murrell MC (1998) Microzooplankton herbivory and phytoplankton growth in the northwestern Sargasso Sea. Aquat Microb Ecol 16:173-188

Levinsen H, Nielsen TG, Hansen BW (2000) Annual succession of marine pelagic protozoans in Disko Bay, West Greenland, with emphasis on winter dynamics. Mar Ecol Prog Ser 206:119-134

Li QP, Franks PJS, Landry MR (2011) Microzooplankton grazing dynamics: parameterizing grazing models with dilution experiment data from the California Current Ecosystem. Mar Ecol Prog Ser 438:59-69

> Litaker RW, Tester PA, Duke CS, Kenney BE, Pinckney JL, Ramus J (2002) Seasonal niche strategy of the bloomforming dinoflagellate Heterocapsa triquetra. Mar Ecol Prog Ser 232:45-62

Löder MGJ, Meunier C, Wiltshire KH, Boersma M, Aberle N (2011) The role of ciliates, heterotrophic dinoflagellates and copepods in structuring spring plankton communities at Helgoland Roads, North Sea. Mar Biol 158: 1551-1580

Martin J (1965) Phytoplankton-zooplankton relationships in Narragansett Bay. Limnol Oceanogr 10:185-191 
Martin JH (1970) Phytoplankton-zooplankton relationships in Narragansett Bay. 4. Seasonal importance of grazing. Limnol Oceanogr 15:413-418

Menden-Deuer S, Fredrickson K (2010) Structure-dependent, protistan grazing and its implication for the formation, maintenance and decline of plankton patches. Mar Ecol Prog Ser 420:57-71

Menden-Deuer S, Lessard EJ (2000) Carbon to volume relationships for dinoflagellates, diatoms, and other protist plankton. Limnol Oceanogr 45:569-579

Menden-Deuer S, Lessard EJ, Satterberg J, Grunbaum D (2005) Growth rates and starvation survival of three species of the pallium-feeding, thecate dinoflagellate genus Protoperidinium. Aquat Microb Ecol 41:145-152

> Miller CA, Penry DL, Glibert PM (1995) The impact of trophic interactions on rates of nitrogen regeneration and grazing in Chesapeake Bay. Limnol Oceanogr 40: 1005-1011

Moigis A (2006) The clearance rate of microzooplankton as the key element for describing estimated non-linear dilution plots demonstrated by a model. Mar Biol 149: 743-762

> Olson RJ, Sosik HM (2007) A submersible imaging-in-flow instrument to analyze nano-and microplankton: Imaging FlowCytobot. Limnol Oceanogr Methods 5:195-203

> Oviatt C, Keller A, Reed L (2002) Annual primary production in Narragansett Bay with no bay-wide winter-spring phytoplankton bloom. Estuar Coast Shelf Sci 54: 1013-1026

Palomares-Garcia R, Bustillos-Guzman JJ, Lopez-Cortes D (2006) Pigment-specific rates of phytoplankton growth and microzooplankton grazing in a subtropical lagoon. J Plankton Res 28:1217-1232

Pratt DM (1959) The phytoplankton of Narragansett Bay. Limnol Oceanogr 4:425-440

Price N, Harrison P, Landry M, Azam F, Hall K (1986) Toxic effects of latex and Tygon tubing on marine phytoplankton, zooplankton and bacteria. Mar Ecol Prog Ser 34: 41-49

Putland JN (2000) Microzooplankton herbivory and bacterivory in Newfoundland coastal waters during spring, summer and winter. J Plankton Res 22:253-277

Rose JM, Caron DA (2007) Does low temperature constrain the growth rates of heterotrophic protists? Evidence and implications for algal blooms in cold water. Limnol Oceanogr 52:886-895

Rose J, Feng Y, Gobler C, Gutierrez R, Hare C, Leblanc K, Hutchins D (2009) Effects of increased $\mathrm{pCO}_{2}$ and temperature on the North Atlantic spring bloom. II. Microzooplankton abundance and grazing. Mar Ecol Prog Ser 388: $27-40$

Editorial responsibility: Antonio Bode, A Coruña, Spain
Saito H, Ota T, Suzuki K, Nishioka J, Tsuda A (2006) Role of heterotrophic dinoflagellate Gyrodinium sp. in the fate of an iron induced diatom bloom. Geophys Res Lett 33:L09602, doi:10.1029/2005GL025366

> Sherr EB, Sherr BF (2007) Heterotrophic dinoflagellates: a significant component of microzooplankton biomass and major grazers of diatoms in the sea. Mar Ecol Prog Ser 352:187-197

Sherr EB, Sherr BF, Hartz AJ (2009) Microzooplankton grazing impact in the Western Arctic Ocean. Deep-Sea Res II 56:1264-1273

Smayda TJ (1998). Patterns of variability characterizing marine phytoplankton, with examples from Narragansett Bay. ICES J Mar Sci 55:562-573

Sosik HM, Olson RJ (2007) Automated taxonomic classification of phytoplankton sampled with imaging-in-flow cytometry. Limnol Oceanogr Methods 5:204-216

- Strom SL, Fredrickson KA (2008) Intense stratification leads to phytoplankton nutrient limitation and reduced microzooplankton grazing in the southeastern Bering Sea. Deep-Sea Res II 55:1761-1774

> Strom SL, Brainard MA, Holmes JL, Olson MB (2001) Phytoplankton blooms are strongly impacted by microzooplankton grazing in coastal North Pacific waters. Mar Biol 138:355-368

Strom SL, Macri EL, Olson MB (2007) Microzooplankton grazing in the coastal Gulf of Alaska: variations in topdown control of phytoplankton. Limnol Oceanogr 52: 1480-1494

Tamigneaux E, Mingelbier M, Klein B (1997) Grazing by protists and seasonal changes in the size structure of protozooplankton and phytoplankton in a temperate nearshore environment (western Gulf of St. Lawrence, Canada). Mar Ecol Prog Ser 146:231-247

> Turner JT (2002) Zooplankton fecal pellets, marine snow and sinking phytoplankton blooms. Aquat Microb Ecol 27:57-102

Utermöhl H (1958) Zur Vervollkommnung der quantitativen Phytoplankton-Methodik. Mitt Int Ver Theor Angew Limnol 9:1-38

Verity PG (1986) Grazing of phototrophic nanoplankton by microzooplankton in Narragansett Bay. Mar Ecol Prog Ser 29:105-115

Verity $\mathrm{P}$, Villareal $\mathrm{T}$ (1986) The relative food value of diatoms, dinoflagellates, flagellates, and cyanobacteria for tintinnid ciliates. Arch Protistenkd 131:71-84

- Worden AZ, Binder BJ (2003) Application of dilution experiments for measuring growth and mortality rates among Prochlorococcus and Synechococcus populations in oligotrophic environments. Aquat Microb Ecol 30: 159-174

Submitted: November 17, 2011; Accepted: April 17, 2012

Proofs received from author(s): June 28, 2012 